\title{
If you build it, they will change: Evaluating the impact of commuter rail stations on real estate values and neighborhood composition in the Rotterdam-The Hague metropolitan area, the Netherlands
}

Amir Forouhar

Art University of Isfahan

a.forouhar@aui.ac.ir

\author{
Dea van Lierop \\ Utrecht University \\ D.S.vanlierop@uu.nl
}

\begin{abstract}
In many metropolitan regions, transit-oriented developments are built to motivate the use of sustainable travel by promoting urban growth within walking distances of public transport stations. Changes in residential property values are a common way to assess the success of transit-oriented developments. However, studies that focus on property values alone have reported mixed effects. This paper attempts to evaluate the land value impact around commuter rail stations by analyzing the change in property values within the context of the transformation of socio-spatial neighborhood attributes. The study sets out to estimate the effect of Randstad Rail stations using real estate transaction data of residential properties and neighborhood socio-spatial attributes in the Rotterdam-the Hague metropolitan area of the Netherlands covering a period from 1985 to 2018. Adopting a quasi-experimental design, the effect is estimated for properties within different catchment zones around three commuter rail stations using a Difference-in-Differences Model and Multivariate Analysis of Variance. The results demonstrate the overall negative effect of the Randstad Rail on the value of residential properties at a distance equal to or less than 400 meters from the selected rail stations in the range of $-18.8 \%$ to $-11.5 \%$. In contrast, a positive effect is observed for the residential properties located within a radius of 400 to 800 meters from the rail stations, which is estimated to be $+15 \%$ to $+33.2 \%$. The findings also indicate a considerable socio-spatial transformation in the neighborhood composition after the opening of the rail stations in terms of neighborhood population density, land-use density, housing characteristics, and car ownership, which significantly affect the magnitude and direction of the impact.
\end{abstract}

Keywords: Urban rail transit, transit-oriented development, property value, socio-spatial transformation, Difference-in-Differences Model, Randstad Rail, the Netherlands

\section{$1 \quad$ Introduction}

In many regions, the introduction of urban rail transit has been associated with reductions in air pollution, noise, traffic accidents, and road congestion (Anderson, 2014; Baum-Snow, Kahn, \& Voith,

Copyright 2021 Amir Forouhar \& Dea van Lierop

http://dx.doi.org/10.5198/jtlu.2021.1795

ISSN: 1938-7849 | Licensed under the Creative Commons Attribution - Noncommercial License 4.0

The Journal of Transport and Land Use is the official journal of the World Society for Transport and Land Use (WSTLUR) and is published and sponsored by the University of Minnesota Center for Transportation Studies.

\section{Article history:}

Received: May 11, 2020

Received in revised form:

January 15, 2021

Accepted: May 2, 2021

Available online: September 8,

2021 
2005; Yang, Zhang, \& Ni, 2014). In addition, rail projects often result in increased regional accessibility, additional mobility options, and reduced transportation costs (Diaz \& Mclean, 1999; Gallo, 2018; Gutiérrez, 2001). Due to these benefits, one might expect that the demand for these improvements should be reflected by a price premium that buyers or renters are willing to pay (Bartholomew \& Ewing, 2011; Debrezion, Pels, \& Rietveld, 2007; Gallo, 2018; Higgins \& Kanaroglou, 2016). From a theoretical point of view, these positive expectations have their roots in the work of von Thünen (1863), as well as economists such as Alonso (1964), Muth (1969), and Mills (1972) who attempted to explain variations in land values based on bid-rent models. The basic idea behind the bid-rent model is that every agent is prepared to pay a certain amount of money, or premium, depending on the location of a property in relation to a central district. This leads to a rent gradient that declines with distance from the central business district (CBD) for sites that yield equal utility. The dominant factor explaining the difference between land values is therefore accessibility, which is measured by calculating the distance from a given property to the CBD as well as the overall travel time and the associated transportation costs (Debrezion et al., 2007; Duncan, 2011a; Pan, 2019). However, investments in transportation infrastructure, especially rail transit systems, can improve accessibility while reducing transportation costs (Du \& Mulley, 2012; El-Barmelgy, Shalaby, Nassar, \& Ali, 2014). Thus, it is expected that transport improvements would be capitalized into increases in land and property values. However, the price of a property consists of two parts: one is the value of the building itself and the other is the value of the land. Normally, changes in property prices are the result of the change in the value of the land rather than the change in the value of buildings, if there is no substantial improvement work on the building (Du \& Mulley, 2007; C. D. Higgins \& Kanaroglou, 2016). In addition, and according to bid-rent theory, due to increased accessibility, properties around rail stations would be expected to become relatively more attractive compared to those located at an equal distance from the CBD, but farther from a rail station, and thus the bidding process would push prices up (Bartholomew \& Ewing, 2011; Debrezion et al., 2007; Gallo, 2018; Higgins \& Kanaroglou, 2016).

The relationship between the proximity to railway stations and property values has increasingly been brought into question since the early 2000s. Studying changes in land values can provide profound insight into many aspects of the urban real estate market (Bowes \& Ihlanfeldt, 2001; Debrezion et al., 2007). Regarding transit infrastructure, research into the land value impact of urban rail transit, a process commonly referred to as land value uplift, is of paramount importance for planners and policymakers as changes in land values can provide evidence of a rail transit project's larger social, environmental, and economic benefits (or potentially a lack thereof) (Higgins \& Kanaroglou, 2016).

Land value uplift around rail infrastructure is a common way for planners and policymakers to assess the success of transit-oriented development (TOD). Since the TOD aims to create more desirable places to live by developing mixed-use, compact, livable, and pedestrian-friendly transit-oriented community growth, the value of these benefits is expected to be capitalized into the prices of nearby properties, especially when the new rail service provides a substantial benefit to the community (Ann, Jiang, \& Yamamoto, 2019; Higgins \& Kanaroglou, 2016; Zhang, Meng, Wang, \& Xu, 2014). Land value uplift related to rail transit can also provide a convincing rationale for engaging in land value capture, a mechanism by which the public sector seeks to recapture the value of benefits received by property owners or developers due to infrastructure improvements, and use these revenues to fund such improvements (Higgins \& Kanaroglou, 2016; McIntosh, Newman, Trubka, \& Kenworthy, 2017; Zhao \& Levinson, 2012). Land value capture has become increasingly attractive as an alternative source of capital for financing rail transit projects, especially in circumstances with widespread fiscal restraints (Haider \& Donaldson, 2016; McIntosh et al., 2017; Smith \& Gihring, 2006; Xiao, Zhong, Zhou, \& Zhou, 2018). However, empirical studies on the impact of rail system land value uplift interventions 
demonstrate mixed findings concerning the magnitude and direction of the results and a dramatic range of both positive and negative effects on residential property values (Debrezion et al., 2007; Diaz \& Mclean, 1999; Higgins \& Kanaroglou, 2016). From a regional planning perspective, it is important to identify the underlying factors associated with rail transit investments that contribute to positive and negative changes in property values (Bowes \& Ihlanfeldt, 2001; Diaz \& Mclean, 1999; Immergluck, 2009). Depending on these factors, strategies and policies can be developed to better predict increases in property prices at different distances from new rail stations, which can be beneficial to meet regional planning objectives, especially in rapidly urbanizing and growing urban regions.

In this study, we argue that rapid transit projects rarely occur in isolation from other changes in the urban system. Therefore, estimating the land value uplift around rail transit stations without considering the overall changes in the surrounding neighborhoods is an unrealistic and insufficient way to identify the dynamic process and its potential underlying factors. Based on an empirical study of the RandstadRail in the Rotterdam-The Hague metropolitan area in the west of the Netherlands, and using a Difference-in-Differences (DID) model, this paper contributes to the body of literature by connecting the change in property values with the transformation of socio-spatial attributes of the neighborhoods around rail transit stations. This context-sensitive approach not only captures any possible changes in the socio-spatial characteristics of neighborhoods after the opening of a rail station, but also reveals the socio-spatial contextual factors which are likely to affect the magnitude and direction of the impact of rail transit stations on residential property values. Thus, the objectives of the present paper are to (1) assess the impact of commuter rail stations on residential property values, and (2) gain an understanding of the socio-spatial transformations of neighborhoods around rail stations along the RandstadRail in Rotterdam-The Hague metropolitan area of the Netherlands.

\section{Literature review}

There is a plethora of academic research on the relationship between the presence and introduction of (new) rail transit stations and real estate values (For example see: Debrezion et al., 2007; Higgins \& Kanaroglou, 2016; Mohammad, Graham, Melo, \& Anderson, 2013). Most studies examined changes in residential rather than commercial property prices, given the often greater amount of space devoted to residential properties compared to commercial properties (Cervero \& Duncan, 2002; Debrezion et al., 2007; Diaz \& Mclean, 1999). The literature offers evidence that rail transit has generally had a positive effect on residential property values located within walking distances of a rail access point, though results differ among modes, contexts, and across analysis types (Cervero, Murphy, \& Ferrell, 2004; Debrezion et al., 2007; Diaz \& Mclean, 1999; Higgins \& Kanaroglou, 2016). On the contrary, the positive nature of the correlation between rail transit service and residential property values has also been challenged by the studies that reported negligible or even negative effects after the introduction of a new rail transit. In these cases, the decline in property values was often reported to be due to negative externalities associated with rail transit systems, such as higher traffic congestion, crime rates, unpleasant noise, vibration, and pollution (Debrezion et al., 2007; Forouhar \& Hasankhani, 2018; Kim \& Zhang, 2005; Mohammad, Graham, \& Melo, 2017; Wardrip, 2011). The recent empirical studies summarized in Appendix A also exhibit a dramatic variation in the estimated impact of heavy rail or commuter rail systems on residential property values, ranging from very high rates of uplift to insignificant, negligible, or even negative, and sometimes contradictory results between studies in the same city.

Since no consistent relationship has been clearly established between a residential property's proximity to a railway station and its value, several studies have set out to reveal the determinants of heterogeneous findings across different case studies. For example, some studies went beyond analyzing housing 
features, and determined that the impact of a rail transit station on the property values largely depends on transportation factors such as levels of service provided in terms of frequency, network connectivity, service coverage, the related facilities as well as the presence of other transportation modes (Bowes \& Ihlanfeldt, 2001; Brinckerhoff, 2001; Cervero \& Duncan, 2002; Cervero, Ferrell, \& Murphy, 2002; Damm, Lerman, Lerner-Lam, \& Young, 1980; Debrezion, Pels, \& Rietveld, 2011). The results of many of these studies suggest that commuter and heavy railway stations show a significantly higher impact on property values compared to most light rail networks due to their stronger performance characteristics (e.g., in terms of speed, regional access, and higher service coverage) (Brinckerhoff, 2001; Cervero, 1984; Debrezion et al., 2007; Landis, Guhathakurta, Huang, Zhang, \& Fukuji, 1995). Furthermore, Pan (2019) and Cervero and Duncan (2002) suggested that as a transit system matures, its service area and frequency of service tends to increase, and thus, residents of communities with more mature transit systems often start to place a greater value on transit access. Other scholars have suggested that the variation in the findings could also be related to contextual factors including changes to the regional economy and public policies (Cervero et al., 2004; Guiliano \& Agarwal, 2010; Higgins, Ferguson, \& Kanaroglou, 2014; Loukaitou-Sideris, 2010; Wardrip, 2011), demographic and socio-economic factors (Bowes \& Ihlanfeldt, 2001; Forouhar, 2016; Hess \& Almeida, 2007; Nelson, 1992), and the design, accessibility, and quality of the urban environment (Atkinson-Palombo, 2010; Bartholomew \& Ewing, 2011; Duncan, 2011b; Kittrell, 2012).

Several studies have also critically reviewed the method used for measuring land value uplift around transit stations, suggesting that reverse causality, omitted variables, and unobserved relationships are possible sources of bias (Debrezion et al., 2007; Duncan, 2011a; Higgins \& Kanaroglou, 2016; Kuminoff, Parmeter, \& Pope, 2010; Wardrip, 2011). Although the majority of empirical studies have utilized hedonic price (HP) models as a powerful tool for estimating land value uplift around rapid transit stations, the accuracy of HP models has been undermined due to the potential for unobserved spatial dependencies, the misspecification of omitted variables, or because of possible confounding effects related to unobserved attributes (Higgins \& Kanaroglou, 2016; Kuminoff et al., 2010; Wardrip, 2011). To control for unobserved spatial dependency and spatial heterogeneity, some researchers have attempted to revise general hedonic models by adding spatially lagged dependent variables, error terms, spatial fixed effects, or by applying local spatial analytical methods, such as geographically weighted regressions (Anselin, 1988; Higgins \& Kanaroglou, 2016; Kuminoff et al., 2010; Ransom, 2018). Nevertheless, the inherently spatial nature of the data utilized in hedonic methods leaves considerable potential for problematic spatial dependence and heterogeneity, thereby requiring many aspects that could possibly affect land value to be controlled for (Higgins \& Kanaroglou, 2016). Moreover, the majority of studies utilizing hedonic models have adopted a cross-sectional design which cannot establish a causal link between rail access and property value over time (Duncan, 201 1a; Higgins \& Kanaroglou, 2016; Wardrip, 2011). In response to these concerns, an emerging set of studies has adopted a Difference-in-Differences (DID) approach to estimate the land value uplift around rail lines and stations (Agostini \& Palmucci, 2008; Ahlfeldt, 2013; Diao, Leonard, \& Sing, 2017; Dubé, Thériault, \& Des Rosiers, 2013; Forouhar \& Hasankhani, 2018; Mohammad et al., 2017; Ransom, 2018; Wagner, Komarek, \& Martin, 2017; Yen, Mulley, Shearer, \& Burke, 2018). The DID approach is less common compared to the traditional HP modeling approach because it requires access to data over a much longer period of time and more case/control neighborhoods. Yet, when the appropriate data is available, the empirical experiences have strongly suggested that the DID modeling approach is a powerful quasi-experimental method for reducing bias from omitted variables and confounding effects compared to HP models and other crosssectional studies (Higgins \& Kanaroglou, 2016; Kuminoff et al., 2010). 
The present paper analyzes the effect of the introduction of the RandstadRail on housing values within the context of neighborhood transformation in the Rotterdam-The Hague metropolitan area in the west of the Netherlands. The RandstadRail is an important rapid transit network in the west of the Netherlands which not only connects the second-largest Dutch city (Rotterdam) with the seat of the national government (The Hague) but also serves a wide range of towns and urban neighborhoods. The present paper contributes to the literature by making land value uplift models more sensitive to station area context and neighborhood composition by connecting the change in property values with the transformation of socio-spatial factors relating to land-use, transportation, and population demographics. This context-sensitive approach not only evaluates the possible changes in residential property values around rail stations but is also highly informative for identifying the socio-spatial contextual factors which are likely to affect the magnitude and direction of the impact.

\section{$3 \quad$ Methods}

The present paper employs a quasi-experimental method to evaluate the impacts of RandstadRail stations on residential property values. A quasi-experiment is an empirical study design to assess the impacts of the introduction of projects and/or new policy interventions in urban and regional contexts where it is not possible or desirable to randomize individuals or sample treatment and control groups (Lambert \& Bewley, 2016; White \& Sabarwal, 2014). In this method, one group becomes a treated group that has received the treatment, whereas another group is analyzed as a comparison group (control group/nontreated group) that has not received the treatment (DiNardo, 2016; Parmeter \& Pope, 2009). One of the most efficient types of quasi-experimental designs is the Difference-in-Differences (DID) model, which is a statistical technique that can be used to calculate the effect of a treatment (i.e., a new rail service) on an outcome variable (i.e., property value) by comparing the average change for the treatment and control groups over a relatively long period, with at least one time period before the "treatment" (pre-treatment) and at least one time period after the "treatment" (post-treatment) (Abadie, 2005; Conley \& Taber, 2011; Lechner, 2011).

The efficiency of the DID models comes from its ability to control the effect of factors that might be confounded with the intended treatment as well as to circumvent the endogeneity problems that normally arise when making comparisons between heterogeneous individuals (Bertrand, Duflo, \& Mullainathan, 2004; Kuminoff et al., 2010; Lechner, 2011; Mohammad et al., 2017). The main idea is that if two treated and two nontreated groups are subject to the same time trends, calculating the difference of the mean outcomes of treated and controls after the treatment and subtracting the outcome difference that had been there already before the treatment, can be used to remove the effect of confounding factors and omitted variables, since the analysis focusses only on relative changes (Lechner, 2011; Ransom, 2018). In addition, the DID models emphasize the "common trend and bias stability" assumption which implies that if the treated group had not been subjected to the treatment, both treated and control groups would have experienced the same time trends (Lechner, 2011; Ransom, 2018; Wing, Simon, $\&$ Bello-Gomez, 2018). This approach also removes biases in post-intervention period comparisons between the treatment and control groups that could be the result of permanent differences between those groups, as well as biases from comparisons over time in the treatment group that could be the result of trends due to other causes of the outcome (Bertrand et al., 2004; Lechner, 2011). The functional form of the DID model used in this study is a semi-log form:

$$
\ln \left(\text { price }_{g t}\right)=\beta_{0}+\beta_{1} T_{g}+\beta_{2} P_{t}+\sum \beta_{3}\left(T_{g} \times P_{t}\right)+\beta_{4} X_{g t}+\sum \beta_{5} \text { year }{ }_{g t}+\sum_{j=1}^{12} \beta_{6} \text { month }_{g j}+\epsilon_{g t}
$$


Where price $_{g t}$ is the outcome of interest which is the real estate transaction price in this case; $T_{g}$ is a treatment group dummy which takes a value of $T_{g}=1$ for the treated group, in this case, the group which experienced a new rail station, and then $\beta_{1}$ represents possible differences between the treatment and control groups before the intervention; $P_{t}$ is a time dummy which takes a value of $P_{t}=1$ for the time after treatment, and $\beta_{2}$ captures aggregate factors that would cause changes in $Y_{g t}$ even in the absence of the treatment; $T_{g} \times P_{t}$ demonstrates the interaction between time and treatment, and $\beta_{3}$ by itself is the difference-in-differences estimator which refers to the causal effect of the given treatment; $X_{g t}$ is a time-varying covariate, in this case, allows us to take into account the property-related structural characteristics and neighborhood socio-spatial attributes; the term $\sum \beta_{5}$ year ${ }_{g t}$ controls for general increases in price due to inflation, whereas $\sum_{\mathrm{j}=1}^{12} \beta_{6}$ month $_{g j}$ controls for seasonal variation; and $\epsilon_{g t}$ is the residual term.

Similar to previous studies that adopted a DID model to examine changes in land values after the opening of a rail station, the present study defines treated properties as those located within a given distance of a station, while control properties are those located at a greater distance. In this study, two consecutive catchment zones are considered for the treated properties; the first includes the residential properties which are located at a distance equal to or less than 400 meters from the central point of the new rail stations, and the second treated group is defined as those located at a distance between 400 to 800 meters of the rail stations. These thresholds are chosen for various reasons. First, a large number of studies have proposed that a 10-minute walk from a station, which is an approximately 800 meter (1/2 mile) radius, is an acceptable catchment area to evaluate the land use and socioeconomic impacts of transit, prescribe regulations such as the relaxation of restrictive zoning, or carve out TOD financial plans (Blainey \& Evens, 2011; Calthorpe, 1993; Ewing, 1999; Guerra, Cervero, \& Tischler, 2012; Higgins \& Kanaroglou, 2016; Landex, Hansen, \& Andersen, 2006; WAP Commission, 1997). Second, several studies have also included smaller boundaries (e.g., $400 \mathrm{~m}$ ) to capture any negative externalities such as noise, vibration, pollution, or crime associated with being relatively too close to a transit station (Bowes \& Ihlanfeldt, 2001; Debrezion et al., 2011; Forouhar \& Hasankhani, 2018; Mohammad et al., 2017). Accordingly, in this study, the catchment zone for treated properties is divided into two consecutive thresholds to examine how the magnitude and direction of the effects change with increased distance from the station. These thresholds are located at $400 \mathrm{~m}$ and $800 \mathrm{~m}$ from the stations.

The control properties are located outside the catchment area at $1000 \mathrm{~m}-1600 \mathrm{~m}$ from the station (see fig. 1). Due to the fact that the case stations included in this study are located in a relatively small urban area, it was methodologically inappropriate to use the more objective approach of using a Propensity Score Matching (PSM) method which in other situations has been used to efficiently reduce the bias resulting from the differences between the treatment and control groups (Billings, 2011; Mulley, Sampaio, \& Ma, 2017). Instead, the control zones used in this paper are selected based on the properties scale through the use of the common trend and bias stability assumption of the DID model which suggests that if the treated area had not been subjected to the treatment (in this case the introduction of a rail station served by public transport), both treated and control groups would have been expected to experience the same time trends (Lechner, 2011; Ransom, 2018; Wing et al., 2018). To satisfy this assumption, we compared the trend of housing prices between the catchment areas and the control zones before the introduction of the rail stations. This examination guarantees that both treated and control groups had the same housing market trend before the introduction of the rail stations. In addition, the present paper attempts to select the threshold of the control properties according to the similarities in land use and population characteristics between the catchment areas and the control zones. Therefore, the control properties located in different contexts (such as non-urbanized areas) are excluded from the dataset. Thus, the maximum possible distance from the stations with the aforementioned conditions 
is selected as the control zone which covers an area between 1000 meters and 1600 meters of the rail stations. The effect of each rail station on residential property values is separately examined for both the treated groups, compared to the control properties. To consider the control variables which can influence property values, the housing characteristics and socio-spatial contextual variables are included in the DID regression models.

In an additional stage of analysis, this paper seeks to explore the socio-spatial transformation that may have occurred in the surrounding neighborhoods after the opening of the rail stations using a Multivariate Analysis of Variance (MANOVA). MANOVA is a generalized form of univariate analysis of variance (ANOVA) that is extended to assess whether changes or interactions between independent variables have significant effects on two or more dependent variables (Azen \& Budescu, 2006; Fish, 1988; Zientek \& Thompson, 2009). This study specifically uses MANOVA to investigate the effect of interaction between independent variables (the interaction between a Time dummy and the Treatment group dummy) on multiple dependent variables (socio-spatial contextual factors of neighborhoods).

\section{$4 \quad$ Context and empirical study}

The Randstad is the name given to the densely populated western rim of the Netherlands, which encompasses the four largest Dutch cities (Amsterdam, Rotterdam, The Hague, and Utrecht) and their surrounding areas. With a population of 8.2 million people - nearly half of the country's population - and a population density of $1,500 / \mathrm{km}^{2}$, it is one of the most economically important and densely populated metropolitan regions in Europe (Manshanden \& Koops, 2017; RandstadRegion, 2017). In addition, the Randstad not only plays a key role in the Dutch transportation network since most intercity connections terminate in one of the main cities in the Randstad, but it also is a critical point of access for Northwestern Europe to the rest of the world (RandstadRegion, 2017; Spaans \& Stead, 2015; van Eck, Snellen, \& Planbureau, 2006).

The urban development concept that has recently most strongly shaped the Randstad is the concept of the Compact City, which has its roots in Dutch planning and policy dating back to the 1980s. This policy mainly focused on re-concentrating development in major urban centers in response to the suburbanization process which had increasingly taken place in the Netherlands after World War II (Pojani \& Stead, 2014). Accordingly, Dutch planning policy actively developed rail lines to link rural communities and small towns to the major cities (Kasraian, Maat, \& van Wee, 2016). In this regard, the RandstadRail has emerged from a long-envisioned urban plan in the Randstad South Wing (especially the Rotterdam-The Hague metropolitan area). It connects the second-largest Dutch city, Rotterdam, with Den Haag (The Hague), the seat of national government by means of a metro line (Line E) and two tram lines (Line 3 and Line 4). In the 2000s and 2010s, Dutch local and regional governments, Netherlands Railways (NS), and the National Rail Network Manager (ProRail) worked together in the south wing of the Randstad (Zuidvleugel) to implement a regional TOD program called StedenbaanPlus (Puello \& Geurs, 2015). The project aimed to densify urbanization in neighborhoods around more than thirty railway stations and improve the accessibility of station areas with the goal of increasing rail ridership (Spaans \& Stead, 2015; StedenbaanPlus, 2013).

The present paper focuses on the RandstadRail Metro Line (Line E) to assess the effects of commuter railway stations on housing prices in the context of the socio-spatial transformation of neighborhoods. The RandstadRail Metro Line currently runs between the Slinge Metro Station in the south of Rotterdam and Den Haag Central station in The Hague. A set of criteria was used to select the case stations for this study. The first criterion was related to the opening year of the rail stations. Many currently operating RandstadRail metro stations are the direct conversion of the former railway network-the 
Spoorlijn Rotterdam Hofplein Scheveningen - which served as a connection between Rotterdam and The Hague. Accordingly, stations that had already been in operation as part of this former railway network were excluded as possible case studies because the effects of previous usage were unclear. Therefore, we considered only the new stations which had been added along the line after 2006 (the operation year of RandstadRail) to separate the effect of RandstadRail from the former rail service. Two of the stations included in this analysis opened for the first time in 2006, and one in 2008; at these locations there were no previous stations and commuter rail services. Another criterion was related to the geographic location of the stations. Since the study attempts to decrease the potential of unobserved attributes, we did not include the stations located near the central business districts (CBDs) or industrial areas, since factors such as zoning restrictions and environmental concerns have been found to play a role in housing prices in these areas (Bergeijk \& Murshes, 2012; Bowes \& Ihlanfeldt, 2001; Chen \& Hao, 2008; Gaolu, 2015). Finally, the available data also presented a limitation associated with the longitudinal nature of the dataset because for some stations there were not enough cases to warrant inclusion in the analysis. Thus, we removed stations that had fewer than 1000 valid real estate transactions between 1985 to 2018. Using these criteria, we selected three rail stations and three catchment zones which are illustrated in Figure 1.

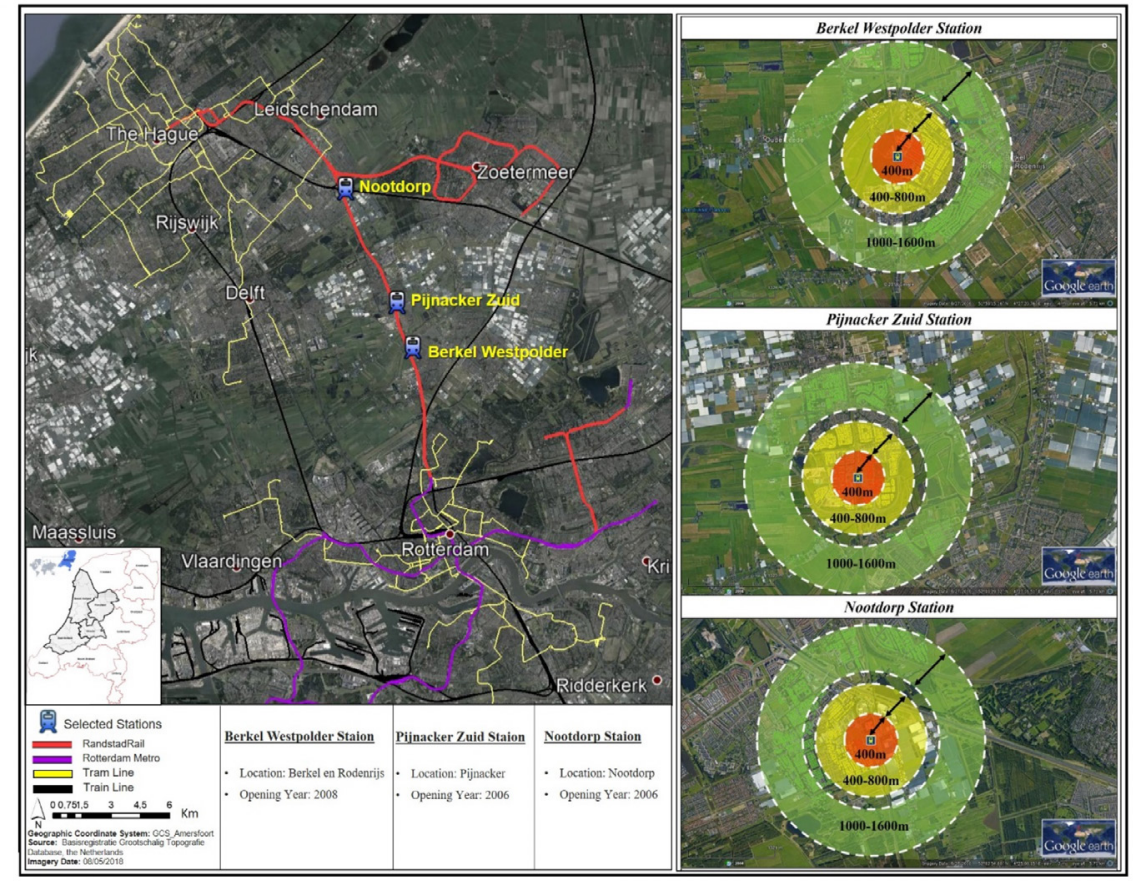

Figure 1. RandstadRail network and the selected stations

\section{$5 \quad$ Data}

In this study, we investigate the effect of RandstadRail stations on residential property values through the use of a rich dataset provided by Brainbay Company founded by the Dutch Association of Real Estate Brokers (NVM). The original dataset includes approximately half a million sale transactions of residential properties in the province of Zuid Holland that took place between 1985 and 2018. To prepare the data for analysis, we first geocoded the dataset to select the treatment and control groups based on the distance between the houses and the selected rail stations. Using geographic information systems soft- 
ware (ArcMap version 10.6.1), each of the housing sales was geo-coded by joining the Brainbay data to a postal code file provided by Esri Nederland. Next, three catchment zones were created for the treated and control properties around the rail stations based on the aforementioned rationale in the methods section (fig. 1). In the analyses that follow, repeat sales of the same house over time were considered as separate cases following the hybrid model suggested by Case and Quigley (1991) that combines repeat sales with house-level covariates (hedonics) to make use of all sales.

Accordingly, in this study, we argue that rail transit projects rarely occur in isolation of other changes in a neighborhood. Thus, when estimating the land value change around rail transit stations it is essential to consider the socio-spatial transformation of the surrounding neighborhoods to identify dynamic processes and as well as other potential underlying factors. As discussed by Billings (2011), estimated price gradients are insufficient to identify the impacts of rail transit; instead, estimates of both a price gradient as well as overall neighborhood changes are required to disentangle the effects of neighborhood change after a rail transit station is introduced. In fact, housing prices are determined not only by the demand for the attributes of the dwelling units themselves, but also by the region in which the units are located (Tse, 2002). The neighborhood-level characteristics that tend to have a determining impact on housing prices include the socio-cultural environment, natural environment, economic status of the population, the overall access to employment centers, and other desired urban facilities such as access to high-quality education, health services, restaurants and shops (Krupka \& Noonan, 2009; Tam, Fung, Wang, \& Ma, 2019). Several studies have shown the important role of regional factors at higher geographic levels, including distance to the core of city, or CBD (Miller \& Ibrahim, 1998; Næss, 2012; Zegras, 2010), distance to other employment centers (Miller \& Ibrahim, 1998; Næss, 2012), and employment density (Boarnet \& Sarmiento, 1998). In addition, a number of studies have found that local-scale variables also offer convincing explanatory power, including distance to nearest bus stops and rail station, distance to neighborhood amenities and facilities, population and employment density, average block size, car accessibility, and the presence of mixed residential and commercial land-use (Kitamura, Mokhtarian, \& Laidet, 1997; Manaugh \& El-Geneidy, 2012; Meurs \& Haaijer, 2001; Milakis, Cervero, \& van Wee, 2015; Nasri \& Zhang, 2012).

In the present study, we use "D-variables" (density, diversity, design, destination accessibility, and distance to transit) - coined originally by Cervero and Kockelman (1997) and developed later by Ewing and Cervero (2001) - as core dimensions of the built environment that may impact travel behavior and subsequently property values (Cervero \& Kockelman, 1997; Ewing \& Cervero, 2001, 2010). In this paper, variables used to assess density include: "available land," "number of houses," "population density," "number of inhabitants," "number of households," and "number of immigrants." Diversity is measured by the number of different kinds of land-use in a given area through assessing "land-use density" which refers to the number of houses, offices, schools, and shopping facilities per square kilometers as well as comparing "number of business locations" compared to residential addresses. Destination accessibility is considered as the ease of access to trip attractions by "distance to nearest CBD" and "distance to built-up area." Distance to transit is measured as "distance to commuter rail stations" and "distance to nearest arterial road." Finally, as Meurs and Haaijer (2001) concluded in the context of the Netherlands, decreasing local and regional car accessibility also could shift a significant number of car trips to alternative modes of transportation. Thus, we added "number of cars" and "number of cars per household" to consider car accessibility.

In this respect, the selected socio-spatial variables, acquired from the Netherlands central office of statistics (the CBS), were matched to the housing sales data. The CBS dataset covers a period from 1985 to 2018. There were two limitations to use CBS's dataset in our analysis. First, the data was available only at the neighborhood scale (four-digit postal code); therefore, those neighborhoods that most closely matched with the boundaries of the selected catchment zones were included as the references 
to match the CBS dataset with the housing sales data for each station at a given transaction year. The second limitation was due to the changes in the variables collected by the CBS and changes to variable definitions over time. For example, since 2006, the classification of companies and institutions was significantly changed, and thus, the number of companies and institutions in 2007 was no longer comparable with the previous data. In addition, some additional variables were also added to CBS reports such as the type of households, income of inhabitants, and social security conditions. Thus, we excluded the variables which were inconsistent in the CBS datasets between 1985 and 2018. The resulting dataset was exported into IBM SPSS Software (version 25) for each station and catchment zone. The ultimate dataset contains 12492, 8619, and 9961 valid transactions respectively for Barkel Westpolder, Pijnacker Zuid, and Nootdorp stations, covering a period from 1985 to 2018. The dataset encompasses information related to housing structural characteristics, distance-based locational factors, land-use conditions, population factors, and transportation features which are further described in Table 1.

Table 1. Descriptive statistics of contextual variables

\begin{tabular}{|c|c|c|c|c|c|c|c|}
\hline Category & Variable Name & $\begin{array}{l}\text { Variable } \\
\text { Type }\end{array}$ & Minimum & Maximum & Mean & $\begin{array}{l}\text { Std. } \\
\text { Deviation }\end{array}$ & Source \\
\hline \multirow[t]{9}{*}{ Structural Factors } & Transaction price (euro/m²) & scale & 166 & 5899 & 2085.32 & 695.61 & Brainbay \\
\hline & Construction date & nominal & before 1500 & $\begin{array}{l}\text { from } 2001 \\
\text { onwards }\end{array}$ & - & - & Brainbay \\
\hline & Insulation & nominal & $\begin{array}{l}\text { without } \\
\text { insulation }\end{array}$ & fully insulated & - & - & Brainbay \\
\hline & Surface area $\left(\mathrm{m}^{2}\right)$ & scale & 70 & 450 & 139.94 & 33.56 & Brainbay \\
\hline & Number of balconies & scale & 0 & 2 & .08 & .29 & Brainbay \\
\hline & Number of floors & scale & 1 & 5 & 2.79 & .55 & Brainbay \\
\hline & Number of toilets & scale & 1 & 4 & 1.38 & .62 & Brainbay \\
\hline & Garden area $\left(\mathrm{m}^{2}\right)$ & scale & 15 & 1925 & 78.85 & 78,17 & Brainbay \\
\hline & Garage & dummy & $\begin{array}{l}\text { without } \\
\text { garage }\end{array}$ & with garage & - & - & Brainbay \\
\hline \multirow[t]{3}{*}{ Location Factors } & Distance to nearest CBD $(\mathrm{km})$ & scale & 1.823 & 5.342 & 2.732 & .453 & CBS \\
\hline & $\begin{array}{l}\text { Distance to nearest arterial } \\
\operatorname{road}(\mathrm{Km})\end{array}$ & scale & .143 & 2.331 & .972 & .260 & CBS \\
\hline & Distance to built-up area & dummy & $\begin{array}{l}\text { inside built- } \\
\text { up area }\end{array}$ & $\begin{array}{l}\text { outside built- } \\
\text { up area }\end{array}$ & - & - & Brainbay \\
\hline \multirow[t]{4}{*}{ Land-use Factors } & Available land (ha) & scale & 10.00 & 1159.00 & 53.77 & 162.1 & CBS \\
\hline & Land-use density (per km²) & scale & 129.00 & 2518.00 & 877.41 & 300.94 & CBS \\
\hline & Number of houses & scale & 10.00 & 7765.00 & 457.20 & 713.28 & CBS \\
\hline & Number of business locations & scale & 1.00 & 870.00 & 33.51 & 56.04 & CBS \\
\hline \multirow[t]{4}{*}{ Population Factors } & Population density (per km²) & scale & 19.00 & 10752.00 & 4920.10 & 3360.88 & CBS \\
\hline & Number of inhabitants & scale & 20.00 & 15940.00 & 1319.86 & 1935.99 & CBS \\
\hline & Number of households & scale & 10.00 & 7830.00 & 459.62 & 714.43 & CBS \\
\hline & Number of immigrants & scale & 32.50 & 6376.00 & 255.41 & 422.93 & CBS \\
\hline \multirow{2}{*}{$\begin{array}{l}\text { Transportation } \\
\text { Factors }\end{array}$} & Number of cars & scale & 15.00 & 5350.00 & 568.81 & 807.73 & CBS \\
\hline & Number of cars per household & scale & .70 & 1.60 & 1.23 & .14 & CBS \\
\hline
\end{tabular}




\section{$6 \quad$ Results}

The results obtained from the DID model are reported in Table 2 for the selected stations and different catchment zones. The table not only demonstrates the impact of opening the selected rail stations on property values, but also specifies the effect of housing structural characteristics, location factors, land-use conditions, population factors, and transportation features on the results. The DID models for residential properties explain between 0.651 and 0.828 percent of the variation in property values for the selected stations. Broadly speaking, the DID estimator demonstrates a negative effect of RandstadRail on the value of residential properties located close to the stations at a distance equal to or less than 400 meters from the rail stations, while a significant positive impact on the residential properties located within a radius of 400 to 800 meters from the rail stations. The results of the DID models indicate that the treatment effects of the RandstadRail on housing values within a 400-meter radius from the selected stations are estimated to be $-18.8 \%,-11.5 \%$, and $-15.3 \%$ respectively for Barkel Westpolder, Pijnacker Zuid, and Nootdorp stations. In other words, the average selling price of treated properties declined after the opening of the selected stations, compared to the control properties which were located within a radius of 1000 to 1600 meters of the rail stations. On the contrary, the DID estimator demonstrates a significant positive effect for properties located in the second catchment zone (400 to 800 meters), compared to the control properties. The treatment effects on the housing values within a radius of 400 to 800 meters from the rail stations indicate $+33.2 \%,+15 \%$, and $+25.8 \%$ for Barkel Westpolder, Pijnacker Zuid, and Nootdorp stations, respectively.

The DID models also yield that the attributes of the dwelling units and the neighborhood composition in terms of accessibility, land-use, population, and transportation features also played a considerable role in changing housing prices in both catchment zones around the rail stations. The models reveal that an increase in housing prices is often associated with improvements in housing facilities such as insulation type, the number of toilets and balconies, and the presence of a garage. Furthermore, an increase in house size (surface area and garden area) and a decrease in the building age of the properties have a positive relationship with the dependent variable. In the case of the Barkel Westpolder station, the total surface area, insulation type, and construction date explain the highest percentage of change in housing prices near to the station, compared to other structural factors. However, the number of balconies does not show a significant relationship. The surface area also has the most explanatory power in the cases of Pijnacker Zuid and Nootdorp stations, as it explains 37.1 and 31.3 percent of the change in housing prices close to the stations, respectively.

In addition, the models demonstrate that all selected locational variables have the expected signs. This means that when the distance from the nearest $\mathrm{CBD}$ and arterial roads increases, the housing value declines when holding all other variables constant. Distance to the nearest CBD explains 54.2, 23.1, and 20.5 percent of the changes in housing prices close to Barkel Westpolder, Pijnacker Zuid, and Nootdorp stations, respectively. The location of residential properties in built-up areas can also positively uplift the housing prices, compared to the properties located in non-urban areas.

Land availability is also estimated to have a strong relationship with the housing values in the DID models. This is mostly an important factor in the context of the Netherlands in which land reclamation has a long history (Hoeksema, 2007). The models reveal that the land availability explains between 21.3 and 61.8 percent of the changes in housing prices close to the selected stations, when holding all other variables constant. Moreover, land-use density — which refers to the number of houses, offices, schools, and shopping facilities per square kilometers - as well as the number of business locations are positively correlated with the price in the catchment areas around the rail stations. For example, in the case of Nootdorp station, the land-use density explains 30.9 percent of the change in housing prices in the first 
catchment zone and 34.6 percent of the change in housing prices within a radius of 400 to 800 meters of the station. The number of business locations also explains 13.6, 9.9, and 9.3 percent of the change in housing prices close to Barkel Westpolder, Pijnacker Zuid, and Nootdorp stations, respectively. The opposite is true for the neighborhoods that have lower levels of land-use mix, meaning that an increase in the total number of residential properties is negatively correlated with price.

Furthermore, the increases in population density and the number of immigrants are shown to significantly uplift property values around the selected stations. For example, in the case of Pijnacker Zuid station, the population density explains 29.4 percent of the change in housing prices in the first catchment zone and 16.0 percent of the change in housing prices within a radius of 400 to 800 meters of the station. The number of immigrants also explains 5.8, 13.2, and 3.8 percent of the change in housing prices close to Barkel Westpolder, Pijnacker Zuid, and Nootdorp stations, respectively. However, in the models, we observe that the number of cars in the household has a negative relationship with the price of houses, showing that an increase in car ownership decreases the housing prices in both catchment zones. The models show that the number of cars explains between 27.4 and 58.3 percent of the change in housing prices close to the selected stations when holding all other variables constant. 
Table 2. Estimating the effect of RandstadRail on residential property values using the difference-in-differences model

\begin{tabular}{|c|c|c|c|c|c|c|c|}
\hline \multirow{4}{*}{ Category } & & \multicolumn{2}{|c|}{ Berkel Westpolder } & \multicolumn{2}{|c|}{ Pijnacker Zuid } & \multicolumn{2}{|c|}{ Nootdorp } \\
\hline & & $\begin{array}{l}\text { Catchment } \\
\text { Zone } 1 \\
\end{array}$ & $\begin{array}{l}\text { Catchment } \\
\text { Zone } 2 \\
\end{array}$ & $\begin{array}{l}\text { Catchment } \\
\text { Zone } 1 \\
\end{array}$ & $\begin{array}{l}\text { Catchment } \\
\text { Zone } 2 \\
\end{array}$ & $\begin{array}{l}\text { Catchment } \\
\text { Zone } 1 \\
\end{array}$ & $\begin{array}{l}\text { Catchment } \\
\text { Zone } 2 \\
\end{array}$ \\
\hline & Overall R Square & .828 & .760 & .698 & .724 & .664 & .651 \\
\hline & F-test & $1101.552^{* * *}$ & $803.288^{* * *}$ & $413.835^{* * *}$ & $526.631^{* * *}$ & $320.725^{* * *}$ & $331.419^{* * *}$ \\
\hline \multirow[t]{7}{*}{ Structural Factors } & Construction Date & $.114^{* * *}$ & $.118^{* * *}$ & $.147^{* * *}$ & $.054^{* * *}$ & $.144^{* * *}$ & $.080^{* * *}$ \\
\hline & Insulation & $.136^{* * *}$ & $.158^{* * *}$ & $.136^{* * *}$ & $.156^{* * *}$ & .014 & $.048^{* * *}$ \\
\hline & Surface area $\left(\mathrm{m}^{2}\right)$ & $.529^{* * *}$ & .006 & $.371^{* * *}$ & $.078^{* * *}$ & $.313^{* * *}$ & $.036^{* *}$ \\
\hline & Number of toilets & $.092^{* * *}$ & $.036^{* * *}$ & $.097^{* * *}$ & $.032^{* * *}$ & $.054^{* * *}$ & .019 \\
\hline & Garden area $\left(\mathrm{m}^{2}\right)$ & $.004^{* *}$ & $.006^{* * *}$ & .008 & $.005^{* *}$ & $.099^{* * *}$ & $.091^{* * *}$ \\
\hline & Number of balconies & .003 & $.050^{* * *}$ & $.094^{* * *}$ & $.056^{* * *}$ & $.048^{* * *}$ & $.025^{* *}$ \\
\hline & Garage & $.107^{* * *}$ & $.141^{* * *}$ & $.243^{* * *}$ & $.176^{* * *}$ & .016 & $.192^{* * *}$ \\
\hline \multirow[t]{3}{*}{ Location Factors } & $\begin{array}{l}\text { Distance to nearest } \\
\mathrm{CBD}(\mathrm{Km})\end{array}$ & $-.542^{* * *}$ & $-.583^{* * *}$ & $-.231^{* * *}$ & $-.050^{* * *}$ & $-.205^{* * *}$ & $-.222^{* * *}$ \\
\hline & $\begin{array}{l}\text { Distance to nearest } \\
\text { arterial road }(\mathrm{Km})\end{array}$ & $-.060^{* * *}$ & $-.061^{* * *}$ & $-.067^{* * *}$ & $-.095^{* * *}$ & $-.022^{* * *}$ & $-.011^{* * *}$ \\
\hline & $\begin{array}{l}\text { Distance to the built- } \\
\text { up area }\end{array}$ & $-.551^{* * *}$ & $-.615^{* * *}$ & $-.195^{* * *}$ & $-.025^{* * *}$ & $-.241^{* * *}$ & $-.233^{* * *}$ \\
\hline \multirow[t]{4}{*}{ Land-use Factors } & Available Land (ha) & $.638^{* * *}$ & $.441^{* * *}$ & $.064^{* * *}$ & $.209^{* * *}$ & $.213^{* * *}$ & .037 \\
\hline & $\begin{array}{l}\text { Land-use density (per } \\
\mathrm{km}^{2} \text { ) }\end{array}$ & $.485^{* * *}$ & -.060 & $.404^{* * *}$ & $.095^{* * *}$ & $.309^{* * *}$ & $.346^{* * *}$ \\
\hline & Number of houses & $-.195^{* * *}$ & $-.099^{* *}$ & $-.048^{* * *}$ & $-.123^{* *}$ & $-.030^{* * *}$ & $-.096^{* *}$ \\
\hline & $\begin{array}{l}\text { Number of business } \\
\text { locations }\end{array}$ & $.136^{* * *}$ & $.112^{* * *}$ & $.099^{* * *}$ & $.077^{* * *}$ & $.093^{* * *}$ & $.167^{* * *}$ \\
\hline \multirow[t]{2}{*}{$\begin{array}{l}\text { Population } \\
\text { Factors }\end{array}$} & $\begin{array}{l}\text { Population density } \\
\left(\text { per } \mathrm{km}^{2}\right)\end{array}$ & $.142^{* * *}$ & $.158^{* * *}$ & $.294^{* * *}$ & $.160^{* * *}$ & $.010^{* * *}$ & $.041^{* * *}$ \\
\hline & $\begin{array}{l}\text { Number of Immi- } \\
\text { grants }\end{array}$ & $.058^{* * *}$ & $.035^{* * *}$ & $.132^{* * *}$ & $.097^{* * *}$ & $.038^{* *}$ & $.127^{* * *}$ \\
\hline $\begin{array}{l}\text { Transportation } \\
\text { Factors }\end{array}$ & Number of cars & $-.583^{* * *}$ & $-.488^{* * *}$ & $-.213^{* * *}$ & $-.088^{* *}$ & $-.274^{* * *}$ & $-.095^{* * *}$ \\
\hline \multirow[t]{2}{*}{ Time } & Month & $.019^{* * *}$ & .001 & $.027^{* * *}$ & $030^{* * *}$ & $.091^{* * *}$ & $.090^{* * *}$ \\
\hline & Year & $.072^{* * *}$ & $.287^{* * *}$ & $.150^{* * *}$ & $.163^{* * *}$ & $.276^{* * *}$ & $.422^{* * *}$ \\
\hline $\begin{array}{l}\text { Difference-in- } \\
\text { Differences } \\
\text { Estimation }\end{array}$ & $\begin{array}{l}\text { Interaction } \\
\text { (Time*Group) }\end{array}$ & $-.188^{* * *}$ & $.332^{* * *}$ & $-.115^{* * *}$ & $.150^{* * *}$ & $-.153^{* *}$ & $.258^{* * *}$ \\
\hline
\end{tabular}

Legend: ${ }^{*} \mathrm{p}=.10 ;{ }^{* *} \mathrm{p}=.05 ;{ }^{* * *} \mathrm{p}=.01$. Values represent Standardized Coefficients Beta for each variable. All entered independent variables satisfy a VIF of less than 2.5 .

The results obtained from the Multivariate Analysis of Variance (MANOVA) suggest that the neighborhoods located near the selected stations (in both the treated catchment zones) experienced a considerable socio/spatial transformation after the opening of the rail stations compared to the control neighborhoods (Table 3). The findings indicate that the residential properties closest to the rail stations tended to become denser after the opening of the rail stations, since the average surface area of the residential properties decreased in the range of -6.29 to -75.25 square meters, and the number of floors significantly increased around the selected stations, compared to the control properties. For example, while the average surface area of the residential properties located in the control zone of Barkel Westpol- 
der station increased from 136.86 to 144.10 square meters following the opening of the rail station, the treated properties close to the rail station experienced a decrease from 159.73 to 137.70 square meters. Regarding the changes in the number of floors, the changes near the selected station were more severe compared to the control neighborhoods. For instance, the residential properties located in the control zone of Nootdorp station experienced an increase in their number of floors from 2.53 to 2.92, however the treated properties experienced a more dramatic increase from 2.26 to 2.93 following the opening of the rail station.

The results of the MANOVA also demonstrate a considerable increase in the number of houses, offices, schools, and shopping facilities (land-use density) in both the treated catchment zones following the opening of the selected rail stations, in such a way that the land-use density increased by 352.30 , 302.04, and 676.97 per square kilometer, respectively within a 400-meter radius from Barkel Westpolder, Pijnacker Zuid, and Nootdorp stations. Furthermore, in the neighborhoods close to the selected stations, the total number of houses increased by $500.81,795.42$, and 1466.21 , and the number of business locations rose by $100.89,39.18$, and 166.85 , respectively for Barkel Westpolder, Pijnacker Zuid, and Nootdorp stations. The model also yields that the increase in land-use density significantly happened more intensely close to the rail stations compared to the control neighborhoods. As the land-use density increased by 243.86, 147.85, and 232.3 in the control neighborhoods of Barkel Westpolder, Pijnacker Zuid, and Nootdorp stations respectively, the catchment zones close to the stations experienced a sharper increase in the land-use density by $596.16,449.88$, and 909.27 . This means, that as expected, the areas near the new stations gained greater increases in land-use density.

Population density also increased in both the treated catchment zones following the opening of the selected stations in the range of 1738 to 4638 inhabitants per square kilometer. For example, while the population density in the control zone of Pijnacker Zuid station increased from 6902.20 to 7512.66 per square kilometers following the opening of the rail station, the treated neighborhoods closer to the rail station experienced a sharper increase, changing from 2246.88 to 5185.00 per square kilometer. Subsequently, a significant increase in the number of inhabitants and households is observed around all three stations. In addition, the percentage of immigrant populations had a significant positive correlation with the introduction of the selected rail stations in the range of 3.05 to 18.17 percent. In this respect, the neighborhoods located within a 400-meter radius from the stations experienced a stronger wave of immigration, compared to the control neighborhoods and even the second catchment zones around the selected stations. Considering the change in the transportation features also revealed that opening the rail stations significantly decreased the number of cars per household in the range of 0.022 to 0.188 in both the treated catchment zones around the selected stations even though the total number of cars increased considerably in both treated neighborhoods up to 2046. It should be mentioned that while the number of cars in the control neighborhoods around the selected stations often dropped during the period of the study, the treated neighborhoods close to the stations experienced a considerable increase in the number of cars, most likely due to the increases in population density. 
Table 3. Socio-spatial transformation of the neighborhoods around the rail stations using Multivariate Analysis of Variance

\begin{tabular}{|c|c|c|c|c|c|c|c|}
\hline & & \multicolumn{2}{|c|}{ Berkel Westpolder } & \multicolumn{2}{|c|}{ Pijnacker Zuid } & \multicolumn{2}{|c|}{ Nootdorp } \\
\hline \multirow[t]{3}{*}{ Category } & & $\begin{array}{l}\text { Catchment } \\
\text { Zone } 1\end{array}$ & $\begin{array}{l}\text { Catchment } \\
\text { Zone } 2\end{array}$ & $\begin{array}{l}\text { Catchment } \\
\text { Zone } 1\end{array}$ & $\begin{array}{l}\text { Catchment } \\
\text { Zone } 2\end{array}$ & $\begin{array}{l}\text { Catchment } \\
\text { Zone } 1\end{array}$ & $\begin{array}{l}\text { Catchment } \\
\text { Zone } 2\end{array}$ \\
\hline & Partial Eta Squared & 0.867 & 0.865 & 0.875 & 0.890 & 0.813 & 0.699 \\
\hline & F-test & $1252.142^{* * *}$ & $1310.622^{* * *}$ & $3109.525^{* * *}$ & $2165.279^{* * *}$ & $1985.660^{* * *}$ & $4256.494^{* * *}$ \\
\hline \multirow{2}{*}{$\begin{array}{l}\text { Structural } \\
\text { Factors }\end{array}$} & Surface area $\left(\mathrm{m}^{2}\right)$ & $-29.273^{* * *}$ & $-24.543^{* * *}$ & $-6.292^{* * *}$ & 0.514 & $-75.250^{* * *}$ & $-20.218^{* * *}$ \\
\hline & Number of floors & $0.238^{* *}$ & $0.169^{* * *}$ & $0.290^{* * *}$ & $0.030^{* * *}$ & $0.289^{* * *}$ & $.133^{* * *}$ \\
\hline \multirow[t]{3}{*}{$\begin{array}{l}\text { Land-use } \\
\text { Factors }\end{array}$} & $\begin{array}{l}\text { Land-use density (per } \\
\mathrm{km}^{2} \text { ) }\end{array}$ & $352.299^{* * *}$ & $277.253^{* * *}$ & $302.036^{* * *}$ & $69.991^{* * *}$ & $676.974^{* * *}$ & $286.010^{* * *}$ \\
\hline & Number of houses & $500.811^{* * *}$ & $468.106^{* * *}$ & $795.419^{* * *}$ & $87.286^{* * *}$ & $1466.213^{* * *}$ & $729.485^{* * *}$ \\
\hline & $\begin{array}{l}\text { Number of business } \\
\text { locations }\end{array}$ & $100.888^{* * *}$ & -11.263 & $39.176^{* * *}$ & $-38.242^{* * *}$ & $166.854^{* * *}$ & $17.804^{* * *}$ \\
\hline \multirow[t]{4}{*}{$\begin{array}{l}\text { Population } \\
\text { Factors }\end{array}$} & $\begin{array}{l}\text { Population density (per } \\
\mathrm{km}^{2} \text { ) }\end{array}$ & $4638.663^{* * *}$ & $3789.933^{* * *}$ & $2327.668^{* * *}$ & $1738.397^{* * *}$ & $2611.191^{* * *}$ & $2505.587^{* * *}$ \\
\hline & Number of inhabitants & $1674.402^{* * *}$ & $1505.673^{* * *}$ & $2287.514^{* * *}$ & $216.215^{* *}$ & $4509.106^{* * *}$ & $2448.001^{* * *}$ \\
\hline & Number of households & $523.827^{* * *}$ & $480.425^{* * *}$ & $790.390^{* * *}$ & $113.011^{* *}$ & $1458.585^{* * *}$ & $729.036^{* * *}$ \\
\hline & $\begin{array}{l}\text { Percentage of immi- } \\
\text { grants }\end{array}$ & $18.168^{* * *}$ & $3.054^{* * *}$ & $8.578^{* * *}$ & 4. $017^{* * *}$ & $13.503^{* * *}$ & $3.330^{* * *}$ \\
\hline \multirow{2}{*}{$\begin{array}{l}\text { Transportation } \\
\text { Factors }\end{array}$} & Number of cars & $602.496^{* * *}$ & $556.758^{* * *}$ & $934.350^{* * *}$ & $156.388^{* *}$ & $2046.924^{* * *}$ & $1016.806^{* * *}$ \\
\hline & $\begin{array}{l}\text { Number of cars per } \\
\text { household }\end{array}$ & $-0.087^{* * *}$ & $-0.087^{* * *}$ & $-0.188^{* * *}$ & $-0.188^{* * *}$ & $-0.022^{* *}$ & $-0.116^{* * *}$ \\
\hline
\end{tabular}

Legend: ${ }^{*} \mathrm{p}=.10 ;{ }^{* *} \mathrm{p}=.05 ;{ }^{* * *} \mathrm{p}=.01$. Values represent Unstandardized Coefficients Beta for each variable.

\section{Discussion}

The results of this study contribute to the existing literature by providing a possible explanation of how property values can be differently affected by the presence of commuter rail stations through the use of a context-sensitive approach that connects the change in property values to the socio-spatial transformation of neighborhoods around the rail stations. The results reveal that the introduction of the RandstadRail brought a negative effect on the value of residential properties at a distance equal to or less than 400 meters from the rail stations. However, the results indicate a significant positive effect for properties located within a radius of 400 to 800 meters around the stations. The findings are consistent with the literature in which housing prices located relatively close to rail stations are affected negatively, but those at an intermediate distance and which are beyond the externality effects, benefit from the transportation access provided by the rail stations. For example, in the context of the Netherlands, Debrezion et al. (2011) found that the neighborhoods located immediately next to new stations were affected negatively due to the externality effects as the houses located adjacent to the commuter rail stations (less than 250 meters) sold for lower prices compared to houses located only a few hundred meters from the station. Furthermore, the properties located between 250 and 500 meters of a station were on average about $25 \%$ more expensive than dwellings located at a distance of 15 kilometers or farther. Similarly, in Dubai, the United Arab Emirates, Mohammad et al. (2017) estimated a negative effect between -9\% and $-17.7 \%$ on the value of residential prices within 0.5 kilometer of the stations, but a positive impact of about 13\% for properties located within 701 to 900 meters of the rail stations. AlQuhtani and Anjomani (2019) also concluded that the residential properties that were closer to rail stations in the Dallas 
Fort-Worth metropolitan area experienced lower changes in housing value compared to the properties located farther away from stations. Since the present study captured the negative impacts close to the selected stations nearly a decade after the opening of the stations, the results contradict the findings by Pan (2019), Lee and Sener (2017), Cervero and Duncan (2002), and Chen et al. (1998) who reported that accessibility effects finally negate nuisance as a transit system matures or a significant positive effect would be expected to appear after a reasonable timespan.

The literature insinuates that factors such as noise, vibration, and pollution, which are associated with being too close to a rail line or station, particularly in the case of heavy or commuter rail, may be responsible for observed negative effects (AlQuhtani \& Anjomani, 2019; Bowes \& Ihlanfeldt, 2001; Debrezion et al., 2011; Forouhar \& Hasankhani, 2018; Martínez \& Viegas, 2009; Mohammad et al., 2017). These are also important factors in the context of the Netherlands in which commuter rail lines and stations are often located above ground and near residential neighborhoods. A study on the impact of the nuisance and vibration caused by high-speed railways on housing prices in the Netherlands indicated that the noise produced by Dutch railways negatively affected property prices located adjacent to the rail lines at up to 12 percent (Theebe, 2004). However, the results of the current study indicate that the nuisance effects could simply be a part of the reason behind the mixed estimated effects, and further explanation could lie in the transformation of the surrounding neighborhoods. The results of the current study showed that the opening of the rail stations was often accompanied by a significant increase in population density as well as an increase in the percentage of immigrants residing in the adjacent neighborhoods. This observation is in line with empirical studies conducted by Wang and Chen (2018), Papa et al. (2008), and Transecon Consortium (2003) who reported that high-speed rail significantly contributes to a shift of residents from the city center to peripheral areas. It is worth mentioning that in the current study, the increases in population density and percentage of immigrants were higher in the immediate station area ( $\leq 400$ meters) compared to the 400-800 meters zone. The observed increase in the percentage of immigrants could be related to the fact that newcomers may seek home locations that are within walking distance to transit stations to have good access to potential jobs, retail, education, and other opportunities. At the same time, the number of business locations considerably increased close to the selected rail stations compared to the farther neighborhoods. This finding is in line with those of Pan (2019) and Bowes and Ihlanfeldt (2001), who reported that increases in population density and immigration around rail stations could expand the retail activities and attract businesses and firms to locate around the station areas. However, Bowes and Ihlanfeldt (2001) explained that the population changes around rail stations may give rise to socio-cultural tensions like crime rates which would not be desirable for local residents (Bowes \& Ihlanfeldt, 2001). A study by Forouhar and Hasankhani (2018) also reported that the local identity and privacy of the immediate neighborhoods can become profoundly damaged following the opening of a rail station due to increased population density and the presence of strangers.

On the other hand, the current study also captured a significant transformation in the characteristics of houses and built-up areas close to the case stations which could be related to the negative externalities in the immediate neighborhoods. The findings showed that the residential properties tended to become denser after the opening of the rail stations, since the average surface area of the residential properties decreased and the number of floors in residential buildings increased around the selected stations, compared to the control properties. The results also demonstrated a considerable increase in the number of houses, offices, schools, and shopping facilities (land-use density) in both the treated catchment zones following the opening of the selected rail stations. Thus, the overall findings imply that there is an increasing tendency toward a denser spatial structure around the selected rail stations. The results are consistent with the findings by Kasraian et al., (2016) who reported that rail infrastructure prompted further urban growth in the Randstad, the Netherlands, suggesting that urbanization is more likely to 
occur in the vicinity of the newly opened stations. Although the captured densification around the rail stations is aligned with TOD principles, the success of densification relies on the capacity of existing neighborhoods, and the populations living within those neighborhoods, to adapt to denser ways of living, working, traveling, and socializing. In the context of Dutch planning tradition, especially when the densification involves an increased number of high-rise buildings, business locations, shopping centers, and offices, unlike many North American cities, are not as common in the Netherlands, and culturally not always see as equally desirable. For example, Beenackers, Groeniger, Kamphuis, \& Van Lenthe (2018) argued that Dutch residents often perceive increases in neighborhood population density as a potential risk of nuisance from neighbors, vandalism, pollution, and crime (Beenackers et al., 2018).

The possible change in transportation modal split also could explain the mixed estimated effects presented in this paper. The majority of policymakers focus on the rapid rail transit system as a solution for reducing congestion posed by automobile traffic (Anderson, 2014; Baum-Snow et al., 2005; Neff \& Dickens, 2010; Yang et al., 2014). In this regard, the Ministry of Transport, Public Works and Water Management of the Netherlands has heavily invested in RandstadRail to limit the negative impacts of automobile-based mobility by encouraging people to use public transportation (Ministry of Transport Public Works and Water Management, 2010). However, the current study illustrated a different aspect of this issue. The results reveal that while the number of cars per household has decreased in all three cases in the range of $2 \%$ to $18 \%$, the total number of cars increased by $602.49,934.35$, and 2046.92; respectively within a 400-meter radius from Barkel Westpolder, Pijnacker Zuid, and Nootdorp stations. This increase in the overall number of cars is a result of a higher population density, as well as the total number of inhabitants and households that are present following the opening of the selected rail stations. Although a decrease in the overall mode share of private cars is aligned with the regional sustainability goals, a considerable increase in the total amount of cars in the studied neighborhoods may become problematic. Specifically, the increase in the total number of cars not only poses a potential congestion and pollution threat to the neighborhoods around the rail stations but can also create barriers for implementing successful TOD by threatening the safety and accessibility of pedestrian- and cycling-oriented spaces.

Finally, it is important to mention that the specific socio-cultural context of the Netherlands could also be informative in explaining why the current study found negative effects in the first catchment zone ( $\leq 400$ meters) but positive effects in the second (within a radius of 400 to 800 meters). Although a 10-minute walking distance from a station has become the de facto standard for rail-transit catchment TOD areas, especially in the United States (Guerra \& Cervero, 2013; Higgins \& Kanaroglou, 2016), it appears that the traditional TOD catchment area could be profoundly affected by the Dutch lifestyle which includes higher rates of cycling compared to many other regions. The common principle of planning rail catchment areas to include properties with have a 10-minute access distance still takes effect. However, in a culture where the access mode is often cycling (and adequate bicycle parking is provided at stations), the access distance increases compared to the commonly cited 10-minute walking distance. In fact, for households who have been living in the Netherlands for longer periods, station access distance may be greater since the normative habit of using a bicycle as an access mode increases the acceptable access distance from the rail station. Thus, in this context, the farther reach of the access mode could explain why living in a farther neighborhood could be considered more reasonable and desirable compared to living in the immediate station area where densities are higher, commercial and residential mix is greater, and therefore neighborhood noise levels and other socio-cultural tensions may also be higher. This finding suggests that there is a need to carefully assess context-sensitive paradigms associated with TOD that reflect local specificities and which better evaluate, design, plan, and ultimately result in effective station development interventions. 


\section{Conclusion}

This paper estimated the effect of the RandstadRail in Rotterdam-The Hague Metropolitan Area of the Netherlands on residential property values and neighborhood composition using a Difference-inDifferences (DID) model and Multivariate Analysis of Variance (MANOVA). Based on a longitudinal dataset (1985-2018) around three commuter rail stations, the results indicated an overall negative effect of RandstadRail ranged from $-18.8 \%$ to $-11.5 \%$ on the value of residential properties located within a 400 -meter radius from the selected stations, but a significant positive effect in the range of $+15 \%$ to $+33.2 \%$ for properties located farther away from the rail stations at a distance between 400 to 800 meters, compared to the control group which was defined as the properties located between 1000 to 1600 meters of the rail stations.

The results of this study have suggested that the mixed price effect of the RandstadRail could be related to the transformation of socio-spatial attributes which has occurred in the neighborhoods around the selected rail stations. Apart from the possible nuisance and vibration effects of RandstadRail, the findings indicated that opening the RandstadRail stations was accompanied by a significant increase in overall population density as well as the percentage of immigrants residing in the neighborhoods close to the rail stations. In addition, a considerable densification tendency was captured in the spatial structure of the neighborhoods and housing characteristics around the selected rail stations. In this regard, the land-use density and the number of business locations increased following the opening of the rail stations, and at the same time, the area of the residential properties decreased, compared to the control properties. Moreover, while the number of cars per household decreased in all three cases after the opening of the selected rail stations, the total number of cars significantly increases in the neighborhoods around the stations, likely due to the overall increase in population density. In this respect, the success of densification relies on the capacity of the host neighborhoods, and the populations living within those neighborhoods, to adapt to denser ways of living, working, traveling, and socializing. If the host neighborhood for a rail station does not have the capacity for receiving a high degree of densification, undesirable congestion, neighborhood nuisance, and socio-cultural tensions may be a result. In addition, the negative estimated effects of the RandstadRail on housing values close to the rail stations may imply that TOD-related efforts may have fallen short of what would have been traditionally expected.

The findings of this paper suggest that a better evaluation, planning, and policy intervention associated with TOD could be achieved by carefully considering the context in which it is being applied —in this case, the specific socio-cultural context of the Netherlands. These contextual factors may refer to lifestyle, transportation preferences, construction regulations, developers' interests, and socio-cultural characteristics. In addition, the results of this study suggest that rail transit stations have the ability not only to influence real estate prices, but also to transform the surrounding neighborhoods in terms of sociospatial aspects. Thus, it is imperative that policymakers and urban planners comprehensively consider the possible socio-spatial transformation of neighborhoods around rail transit stations to strengthen the positive impacts and mitigate the possible negative externalities. Finally, testing other international case studies as well as possible case studies in other Dutch cities with different socio-spatial characteristics, and combining the results with a comprehensive discussion on the specific access mode choice in the Netherlands, could lead to additional avenues for future research.

\section{Acknowledgements}

The authors express their gratitude to the Brainbay Company (the Netherlands) for providing the rich property database and to Dr. Joep Steegmans (Utrecht University) who helped to provide access to the 
dataset. We would like to thank all of the reviewers and the editor for their helpful and thorough feedback which helped us significantly improve this study in innumerable ways. The research was supported by the Art University of Isfahan and Iran's National Elites Foundation and by Utrecht University's Department of Human Geography and Spatial Planning. 


\section{References}

Abadie, A. (2005). Semiparametric difference-in-differences estimators. The Review of Economic Studies, 72(1), 1-19.

Agostini, C. A., \& Palmucci, G. A. (2008). The anticipated capitalization effect of a new metro line on housing prices. Fiscal Studies, 29(2), 233-256.

Ahlfeldt, G. M. (2013). If we build it, will they pay? Predicting property price effects of transport innovations. Environment and Planning A, 45(8), 1977-1994.

Alonso, W. (1964). Location and land use: Toward a general theory of land rent. United Kingdom: Harvard University Press.

AlQuhtani, S., \& Anjomani, A. (2019). Do rail transit stations affect housing value changes? The Dallas Fort-Worth metropolitan area case and implications. Journal of Transport Geography, 79, 102463.

Anderson, M. L. (2014). Subways, strikes, and slowdowns: The impacts of public transit on traffic congestion. American Economic Review, 104(9), 2763-2796.

Ann, S., Jiang, M., \& Yamamoto, T. (2019). Re-examination of the standards for transit oriented development influence zones in India. Journal of Transport and Land Use, 12(1), 679-700

Anselin, L. (1988). Lagrange multiplier test diagnostics for spatial dependence and spatial heterogeneity. Geographical Analysis, 20(1), 1-17.

Atkinson-Palombo, C. (2010). Comparing the capitalization benefits of light-rail transit and overlay zoning for single-family houses and condos by neighborhood type in metropolitan Phoenix, Arizona. Urban Studies, 47(11), 2409-2426.

Azen, R., \& Budescu, D. V. (2006). Comparing predictors in multivariate regression models: An extension of dominance analysis. Journal of Educational and Behavioral Statistics, 31(2), 157-180.

Bartholomew, K., \& Ewing, R. (2011). Hedonic price effects of pedestrian-and transit-oriented development. Journal of Planning Literature, 26(1), 18-34.

Baum-Snow, N., Kahn, M. E., \& Voith, R. (2005). Effects of urban rail transit expansions: Evidence from sixteen cities, 1970-2000 [with comment]. Brookings-Wharton Papers on Urban Affairs, 147206.

Beenackers, M. A., Groeniger, J. O., Kamphuis, C. B. M., \& Van Lenthe, F. J. (2018). Urban population density and mortality in a compact Dutch city: 23-year follow-up of the Dutch GLOBE study. Health \& Place, 53, 79-85.

Bergeijk, P., \& Murshes, S. (2012). The relation between land price and distance to CBD in Bekasi. The Hague: International Institute of Social Studies.

Bertrand, M., Duflo, E., \& Mullainathan, S. (2004). How much should we trust differences-in-differences estimates? The Quarterly Journal of Economics, 119(1), 249-275.

Billings, S. B. (2011). Estimating the value of a new transit option. Regional Science and Urban Economics, 41(6), 525-536.

Blainey, S., \& Evens, S. (2011). Local station catchments: Reconciling theory with reality. Paper prestented at the European Transport Conference, Glasgow, Scotland, October 10-12.

Boarnet, M. G., \& Sarmiento, S. (1998). Can land-use policy really affect travel behavior? A study of the link between non-work travel and land-use characteristics. Urban Studies, 35(7), 1155-1169.

Bowes, D. R., \& Ihlanfeldt, K. R. (2001). Identifying the impacts of rail transit stations on residential property values. Journal of Urban Economics, 50(1), 1-25.

Brinckerhoff, P. (2001). The effect of rail transit on property values: A summary of studies (Research carried out for Project S, 21439). Eugene, OR: University of Oregon.

Calthorpe, P. (1993). The next American metropolis: Ecology, community, and the American dream. New York: Princeton Architectural Press. 
Case, B., \& Quigley, J. M. (1991). The dynamics of real estate prices. The Review of Economics and Statistics, 50-58.

Cervero, R. (1984). Journal report: Light rail transit and urban development. Journal of the American Planning Association, 50(2), 133-147.

Cervero, R., \& Duncan, M. (2002). Land value impacts of rail transit services in Los Angeles County. Washington, DC: National Association of Realtors, Urban Land Institute.

Cervero, R., Ferrell, C., \& Murphy, S. (2002). Transit-oriented development and joint development in the United States: A literature review. TCRP Research Results Digest, 52, 1-144.

Cervero, R., \& Kockelman, K. (1997). Travel demand and the 3Ds: Density, diversity, and design. Transportation Research Part D: Transport and Environment, 2(3), 199-219.

Cervero, R., Murphy, S., \& Ferrell, C. (2004). TCRP Report 102: Transit-oriented development in the United States. Washington, DC: Transportation Research Board.

Chen, J., \& Hao, Q. (2008). The impacts of distance to CBD on housing prices in Shanghai: A hedonic analysis. Journal of Chinese Economic and Business Studies, 6(3), 291-302.

Chen, H., Rufolo, A., \& Dueker, K. J. (1998). Measuring the impact of light rail systems on singlefamily home values: A hedonic approach with geographic information system application. Transportation Research Record, 1617(1), 38-43.

Conley, T. G., \& Taber, C. R. (2011). Inference with "difference in differences" with a small number of policy changes. The Review of Economics and Statistics, 93(1), 113-125.

Damm, D., Lerman, S. R., Lerner-Lam, E., \& Young, J. (1980). Response of urban real estate values in anticipation of the Washington metro. Journal of Transport Economics and Policy, 14(3), 315-336.

Debrezion, G., Pels, E., \& Rietveld, P. (2007). The impact of railway stations on residential and commercial property value: A meta-analysis. The Journal of Real Estate Finance and Economics, 35(2), 161-180.

Debrezion, G., Pels, E., \& Rietveld, P. (2011). The impact of rail transport on real estate prices: An empirical analysis of the Dutch housing market. Urban Studies, 48(5), 997-1015.

Diao, M., Leonard, D., \& Sing, T. F. (2017). Spatial-difference-in-differences models for impact of new mass rapid transit line on private housing values. Regional Science and Urban Economics, 67, 64-77.

Diaz, R. B., \& Mclean, V. (1999). Impacts of rail transit on property values. Paper presented at the American Public Transit Association Rapid Transit Conference, Toronto, Canada.

DiNardo, J. (2016). Natural experiments and quasi-natural experiments. The new Palgrave dictionary of economics. https://doi.org/10.1057/978-1-349-95121-5

Du, H., \& Mulley, C. (2007). The short-term land value impacts of urban rail transit: Quantitative evidence from Sunderland, UK. Land Use Policy, 24(1), 223-233.

Du, H., \& Mulley, C. (2012). Understanding spatial variations in the impact of accessibility on land value using geographically weighted regression. Journal of Transport and Land Use, 5(2), 46-59. https://doi.org/10.5198/jtlu.v5i2.225

Dubé, J., Thériault, M., \& Des Rosiers, F. (2013). Commuter rail accessibility and house values: The case of the Montreal South Shore, Canada, 1992-2009. Transportation Research Part A: Policy and Practice, 54, 49-66.

Duncan, M. (2011a). The impact of transit-oriented development on housing prices in San Diego, CA. Urban Studies, 48(1), 101-127.

Duncan, M. (2011b). The synergistic influence of light rail stations and zoning on home prices. Environment and Planning A, 43(9), 2125-2142.

El-Barmelgy, M. M., Shalaby, A. M., Nassar, U. A., \& Ali, S. M. (2014). Economic land use theory and land value in value model. International Journal of Economics and Statistics 2, 91-98. 
Ewing, R., \& Cervero, R. (2001). Travel and the built environment: A synthesis. Transportation Research Record, 1780(1), 87-114.

Ewing, R., \& Cervero, R. (2010). Travel and the built environment: A meta-analysis. Journal of the American Planning Association, 76(3), 265-294.

Ewing, R. H. (1999). Pedestrian-and transit-friendly design: A primer for smart growth. Washington, DC: Smart Growth Network.

Fish, L. J. (1988). Why multivariate methods are usually vital. Measurement and Evaluation in Counseling and Development, 21(3), 130-137.

Forouhar, A. (2016). Estimating the impact of metro rail stations on residential property values: Evidence from Tehran. Public Transport, 8(3), 427-451.

Forouhar, A., \& Hasankhani, M. (2018). The effect of Tehran metro rail system on residential property values: A comparative analysis between high-income and low-income neighborhoods. Urban Studies, 55(16), 3503-3524.

Gallo, M. (2018). The impact of urban transit systems on property values: A model and some evidences from the city of Naples. Journal of Advanced Transportation. https://doi.org/10.1155/2018/1767149

Gaolu, Z. (2015). The effect of central business district on house prices in Chengdu metropolitan area: $A$ hedonic approach. Paper presented at the 2015 AASRI International Conference on Circuits and Systems (CAS 2015), Paris, France, August 9-10.

Guerra, E., \& Cervero, R. (2013). Is a half-mile circle the right standard for TODs? Access Magazine. Retrieved from https:/www.accessmagazine.org/spring-2013/half-mile-circle-right-standard-tods/

Guerra, E., Cervero, R., \& Tischler, D. (2012). Half-mile circle: Does it best represent transit station catchments? Transportation Research Record, 2276(1), 101-109.

Guiliano, G., \& Agarwal, A. (2010). Public transit as a metropolitan growth strategy. Urban and Regional Policy and its Effects (pp. 205-252). Washington, DC: Brookings Institution Press.

Gutiérrez, J. (2001). Location, economic potential and daily accessibility: An analysis of the accessibility impact of the high-speed line Madrid-Barcelona-French border. Journal of Transport Geography, 9(4), 229-242.

Haider, M., \& Donaldson, L. (2016). Can tax increment financing support transportation infrastructure investment? Toronto: Institute on Municipal Finance and Governance.

Hess, D. B., \& Almeida, T. M. (2007). Impact of proximity to light rail rapid transit on station-area property values in Buffalo, New York. Urban Studies, 44(5-6), 1041-1068.

Higgins, C., Ferguson, M., \& Kanaroglou, P. (2014). Light rail and land use change: Rail transit's role in reshaping and revitalizing cities. Journal of Public Transportation, 17(2), 5.

Higgins, C. D., \& Kanaroglou, P. S. (2016). Forty years of modelling rapid transit's land value uplift in North America: Moving beyond the tip of the iceberg. Transport Reviews, 36(5), 610-634.

Hoeksema, R. J. (2007). Three stages in the history of land reclamation in the Netherlands. Irrigation and Drainage: The Journal of the International Commission on Irrigation and Drainage, 56(S1), S113S126.

Immergluck, D. (2009). Large redevelopment initiatives, housing values and gentrification: The case of the Atlanta beltline. Urban Studies, 46(8), 1723-1745.

Kasraian, D., Maat, K., \& van Wee, B. (2016). Development of rail infrastructure and its impact on urbanization in the Randstad, the Netherlands. Journal of Transport and Land Use, 9(1), 151-170.

Kim, J., \& Zhang, M. (2005). Determining transit's impact on Seoul commercial land values: An application of spatial econometrics. International Real Estate Review, 8(1), 1-26.

Kitamura, R., Mokhtarian, P. L., \& Laidet, L. (1997). A micro-analysis of land use and travel in five neighborhoods in the San Francisco Bay Area. Transportation, 24(2), 125-158.

Kittrell, K. (2012). Impacts of vacant land values: Comparison of metro light rail station areas in Phoe- 
nix, Arizona. Transportation Research Record, 2276(1), 138-145.

Krupka, D. J., \& Noonan, D. S. (2009). Neighborhood dynamics and the housing price effects of spatially targeted economic development policy (IZA discussion papers 4308). Bonn, Germany: Institute of Labor Economics.

Kuminoff, N. V., Parmeter, C. F., \& Pope, J. C. (2010). Which hedonic models can we trust to recover the marginal willingness to pay for environmental amenities? Journal of Environmental Economics and Management, 60(3), 145-160.

Lambert, T. E., \& Bewley, M. (2016). The use of quasi-experimental design in urban and regional policy research and political economy. Louisville, KY: University of Louisville, College of Business.

Landex, A., Hansen, S., \& Andersen, J. L. (2006). Examination of catchment areas for public transport. Paper presented at the Selected Proceedings from the Annual Transport Conference, Aalborg University, Aalborg, Denmark.

Landis, J., Guhathakurta, S., Huang, W., Zhang, M., \& Fukuji, B. (1995). Rail transit investments, real estate values, and land use change: A comparative analysis of five California rail transit systems. Berkeley, CA: University of Berkeley, Insitute of Urban and Regional Development.

Lechner, M. (2011). The estimation of causal effects by difference-in-difference methods. Foundations and Trends in Econometrics, 4(3), 165-224.

Loukaitou-Sideris, A. (2010). A new-found popularity for transit-oriented developments? Lessons from Southern California. Journal of Urban Design, 15(1), 49-68.

Manaugh, K., \& El-Geneidy, A. M. (2012). What makes travel 'local': Defining and understanding local travel behavior. Journal of Transport and Land Use, 5(3), 15-27.

Manshanden, W., \& Koops, O. (2017). De Top-20 van Europese grootstedelijke region's 1995-2016. In Randstad Monitor 2016. Brussels: Randstad Monitor.

Martínez, L. M., \& Viegas, J. M. (2009). Effects of transportation accessibility on residential property values: Hedonic Price Model in the Lisbon, Portugal, metropolitan area. Transportation Research Record, 2115(1), 127-137.

McIntosh, J., Newman, P., Trubka, R., \& Kenworthy, J. (2017). Framework for land value capture from investments in transit in car-dependent cities. Journal of Transport and Land Use, 10(1), 155-185.

Meurs, H., \& Haaijer, R. (2001). Spatial structure and mobility. Transportation Research Part D: Transport and Environment, 6(6), 429-446.

Milakis, D., Cervero, R., \& van Wee, B. (2015). Stay local or go regional? Urban form effects on vehicle use at different spatial scales: A theoretical concept and its application to the San Francisco Bay Area. Journal of Transport and Land Use, 8(2), 59-86.

Miller, E. J., \& Ibrahim, A. (1998). Urban form and vehicular travel: Some empirical findings. Transportation Research Record, 1617(1), 18-27.

Mills, E. S. (1972). Studies in the structure of the urban economy. Baltimore: Johns Hopkins University Press.

Ministry of Transport Public Works and Water Management. (2010). Public transport in the Netherlands. The Hague, The Netherlands: Ministry of Transport Public Works and Water Management.

Mohammad, S. I., Graham, D. J., \& Melo, P. C. (2017). The effect of the Dubai metro on the value of residential and commercial properties. Journal of Transport and Land Use, 10(1), 263-290.

Mohammad, S. I., Graham, D. J., Melo, P. C., \& Anderson, R. J. (2013). A meta-analysis of the impact of rail projects on land and property values. Transportation Research Part A: Policy and Practice, 50, 158-170.

Mulley, C., Sampaio, B., \& Ma, L. (2017). South eastern busway network in Brisbane, Australia: Value of the network effect. Transportation Research Record, 2647(1), 41-49. 
Muth, R. F. (1969). Cities and housing. Chicago, IL: University of Chicago Press.

Næss, P. (2012). Urban form and travel behavior: Experience from a Nordic context. Journal of Transport and Land Use, 5(2), 21-45.

Nasri, A., \& Zhang, L. (2012). Impact of metropolitan-level built environment on travel behavior. Transportation Research Record, 2323(1), 75-79.

Neff, J., \& Dickens, M. (2010). 2010 public transportation fact book. Washington, DC: American Public Transportation Association.

Nelson, A. C. (1992). Effects of elevated heavy-rail transit stations on house prices with respect to neighborhood income. Transportation Research Record, 1359, 127-132.

Pan, Q. (2019). The impacts of light rail on residential property values in a non-zoning city. Journal of Transport and Land Use, 12(1), 241-264.

Papa, E., Pagliara, F., \& Bertolini, L. (2008). Rail system development and urban transformations: Towards a spatial decision support system. In Railway development (pp. 337-357). Physica-Verlag HD.

Parmeter, C. F., \& Pope, J. C. (2009). Quasi-experiments and hedonic property value methods. Cheltenham, UK: Edward Elgar Publishing.

Pojani, D., \& Stead, D. (2014). Ideas, interests, and institutions: Explaining Dutch transit-oriented development challenges. Environment and Planning A, 46(10), 2401-2418.

Puello, L. L. P., \& Geurs, K. (2015). Modelling observed and unobserved factors in cycling to railway stations: Application to transit-oriented-developments in the Netherlands. European Journal of Transport and Infrastructure Research, 15(1), 27-50.

RandstadRegion, R. (2017). Randstad monitor 2017. Brussels: Randstand Monitor.

Ransom, M. R. (2018). The effect of light rail transit service on nearby property values. Journal of Transport and Land Use, 11(1), 387-404.

Smith, J. J., \& Gihring, T. A. (2006). Financing transit systems through value capture: An annotated bibliography. American Journal of Economics and Sociology, 65(3), 751-786.

Spaans, M., \& Stead, D. (2015). 10 Integrating public transport and urban development in the southern Randstad. In Territorial governance across Europe: Pathways, practices and prospects. Oxfordshire, England: Taylor and Francis.

StedenbaanPlus, P. (2013). Stedenbaan monitor 2013. In Platform Zuidvleugel. The Hague: Stedenbaan region.

Tam, V. W. Y., Fung, I. W. H., Wang, J., \& Ma, M. (2019). Effects of locations, structures and neighborhoods to housing price: An empirical study in Shanghai, China. International Journal of Construction Management, X, 1-20.

Theebe, M. A. (2004). Planes, trains, and automobiles: The impact of traffic noise on house prices. The Journal of Real Estate Finance and Economics, 28(2-3), 209-234.

Thünen, J. H. v. (1863). Der Isolirte Staat in Beziehung auf Landwirthschaft und Nationalökonomie. Germany: Leopold.

Transecon Consortium (2003) Urban Transport and Local Socio-Economic Development. Institute for Transport Studies, Universität für Bodenkultur Wien.

Tse, R. Y. C. (2002). Estimating neighborhood effects in house prices: Towards a new hedonic model approach. Urban Studies, 39(7), 1165-1180.

Van Eck, J. R., Snellen, D., \& Planbureau, R. (2006). Is the Randstad a city network? Evidence from commuting patterns. Paper presented at the European Transport Conference, September, Strasbourg, France.

Wagner, G. A., Komarek, T., \& Martin, J. (2017). Is the light rail "tide" lifting property values? Evidence from Hampton Roads, VA. Regional Science and Urban Economics, 65, 25-37. 
Wang, L., \& Chen, L. (2018). The impact of new transportation modes on population distribution in Jing-Jin-Ji region of China. Scientific Data, 5(1), 1-15.

WAP Commission. (1997). Liveable neighborhoods: Community design code. Perth, Australia: Western Australia Planning Commission.

Wardrip, K. (2011). Public transit's impact on housing costs: A review of the literature. Washington, DC: U.S. National Housing Conference, Center for Housing Policy.

White, H., \& Sabarwal, S. (2014). Quasi-experimental design and methods. Methodological Briefs: Impact Evaluation, 8, 1-16.

Wing, C., Simon, K., \& Bello-Gomez, R. A. (2018). Designing difference in difference studies: Best practices for public health policy research. Annual Review of Public Health, 39, 453-469.

Xiao, Y., Zhong, H., Zhou, T., \& Zhou, Y. (2018). Rail transit development in lagging regions: A development-oriented investment and financing approach. Journal of Transport and Land Use, 11(1), 1003-1024.

Yang, Y., Zhang, P., \& Ni, S. (2014). Assessment of the impacts of urban rail transit on metropolitan regions using system dynamics model. Transportation Research Procedia, 4, 521-534.

Yen, B. T. H., Mulley, C., Shearer, H., \& Burke, M. (2018). Announcement, construction or delivery: When does value uplift occur for residential properties? Evidence from the Gold Coast Light Rail system in Australia. Land Use Policy, 73, 412-422.

Zegras, C. (2010). The built environment and motor vehicle ownership and use: Evidence from Santiago de Chile. Urban Studies, 47(8), 1793-1817.

Zhang, M., Meng, X., Wang, L., \& Xu, T. (2014). Transit development shaping urbanization: Evidence from the housing market in Beijing. Habitat International, 44, 545-554.

Zhao, Z. J., \& Levinson, D. (2012). Introduction to the special issue on value capture for transportation finance. Journal of Transport and Land Use, 5(1), 1-3.

Zientek, L. R., \& Thompson, B. (2009). Matrix summaries improve research reports: Secondary analyses using published literature. Educational Researcher, 38(5), 343-352.

\section{Appendix}

Appendix available at https://www.jtlu.org/index.php/jtlu/article/view/1795 